\title{
最近の冷間鍛造と材料
}

\section{Recent Contributions of Work and Tool Materials for Cold Forged Products}

Hiromu SAWABE

\section{1. まえがき}

最近，冷間鍛造業界では多品種少量生産にたいする技 術的な対応が叫ばれ, その一環として鍛造による付加価 值の增加, 高精度化, 形状の複雑化の傾向が顕著となり, 今まで主眼としていた粗形材の合理化から, 材料から完 成品にいたる総合的な工程の短縮と原価低隇にたいする 対応性が今後の課題として浮上してきた。それにとも なって被加工材, 工具材など材料にたいする要求が多様 化している.

冷鍛技術は導入以来約 30 年の間に表 1 にしめすよう な過程で順調な発展を遂げ, わが国固有の技術として再 構築された. その背景には型材料, 型の表面処理, 被加
工材料, 潤滑処理, プレス機械など般造をとりまく周辺 技術の長足な進歩が貢献するところが大きい。ここでは 最近の鋼材および金型材料と冷間鍛造とのかかわりにつ いて整理することにした。

\section{2. 冷鍛品にたいする要望}

表 2 にしめすように被加工材料はその製造方法に順次 新しい技術を導入し，自動車産業などおもに冷鍛品の利 用分野からの要請に対応した態勢づくりが進み，その上 に立って冷鍛品もさらに適用範囲を拡大してきた.現在, 冷鍛品にたいして需要家から要望されている問題につい て，あるていど対応が終わっているものから列記すると 次のようになる.

表 1 日本に扩ける冷間鍛造の発展過程

\begin{tabular}{|c|c|c|c|c|c|c|c|c|}
\hline 年 代 & $1950 \Rightarrow 1955$ & $1955 \Leftrightarrow 1960$ & $1960 \Rightarrow 1965$ & $1965 \Leftrightarrow 1970$ & $1970 \Rightarrow 1975$ & $1975 \Rightarrow 1980$ & $1980 \Rightarrow 1985$ & $1985 \Rightarrow 1990$ \\
\hline 環 境 & $\begin{array}{l}\text { 戦後復興期 } \\
\text { 工立第 }\end{array}$ & $\begin{array}{l}\text { 自動車生产の制 } \\
\text { 解除 }\end{array}$ & 睬憅車の基幹産 & QC 思想の導入 & 第一次石油危機 & $\begin{array}{l}\text { 第二次石油危機 } \\
\frac{7}{ク} \text { クシショッ }\end{array}$ & $\mathrm{TQC}$ の確立 & $\begin{array}{l}\text { 田高不況·景気 } \\
\text { 復 }\end{array}$ \\
\hline 経 過 & $\begin{array}{l}\text { 冷錘技術の小規 } \\
\text { 模工業化 }\end{array}$ & $\begin{array}{l}\text { 冷般専業工場の } \\
\text { 出現·各社冷 } \\
\text { 部門新設 }\end{array}$ & 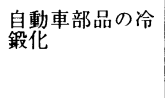 & 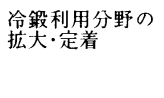 & 冷锻品の大型化 & $\begin{array}{l}\text { 他工洼との複合 } \\
\text { と温銠化 }\end{array}$ & 多種少量生産 & $\begin{array}{l}\text { 熱温冷錪造技術 } \\
\text { 盒理的生産の追 } \\
\text { 求 }\end{array}$ \\
\hline 適 用 & 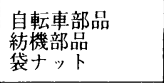 & $\begin{array}{l}\text { オートバイ部品 } \\
\text { スピーカー部品 }\end{array}$ & $\begin{array}{l}\text { 小型自動車部品 } \\
\text { ベリジ外 } \\
\text { 輪 }\end{array}$ & $\begin{array}{l}\text { カメラ小物部品 } \\
\text { 小型ボン゙ } \\
\text { スプライン軸 }\end{array}$ & 大型自動車部品 & 高精度部品 & $\begin{array}{l}\text { 内外歯車類 } \\
\text { 翼形軸部品 }\end{array}$ & $\begin{array}{l}\text { スパイラル菌車 } \\
\text { 非対称部品 }\end{array}$ \\
\hline 目 的 & $\begin{array}{l}\text { 材料節隇 } \\
\text { 施盤己冷鉒 }\end{array}$ & $\begin{array}{l}\text { 大量生産指向 } \\
\text { 低コス生産 }\end{array}$ & 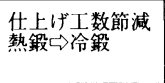 & 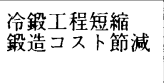 & 冷鍛設計の採用 & $\begin{array}{l}\text { 合理的生産方式 } \\
\text { の組込 }\end{array}$ & $\begin{array}{l}\text { 複雑形状の冷錪 } \\
\text { 华 } \\
\text { 拊価値の追求 }\end{array}$ & 冷鍛品 $=$ 製品 \\
\hline 材 料 & $\begin{array}{l}\text { 低岸素替格鋼の } \\
\text { 供給·介在物の } \\
\text { 隇少 }\end{array}$ & 低炭素合金龬 & $\begin{array}{l}\text { 中宸素合金鎆 } \\
\text { 軸受徐合金 } \\
\end{array}$ & $\begin{array}{l}\text { 冷銭仕㭬材生産 } \\
\text { 連鋳技開発 }\end{array}$ & $\begin{array}{l}\text { 線材品啠向上 } \\
\text { 向気焼鈍普及 }\end{array}$ & $\begin{array}{l}\text { 特定用途鋼の供 } \\
\text { 給 }\end{array}$ & 炉外精錬鋼の普 & 線材の大型化 \\
\hline 重 量 & $\leqq 0.1 \mathrm{~kg}$ & $0.1 \sim 0.3 \mathrm{~kg}$ & $0.3 \sim 0.5 \mathrm{~kg}$ & $0.5 \sim 2.0 \mathrm{~kg}$ & $\leqq 15 \mathrm{~kg}$ & & & \\
\hline プレス & $\begin{array}{l}\text { ナックルプレス } \\
\text { マイ・プレス } \\
(\leqq 200 \mathrm{t})\end{array}$ & $\begin{array}{l}\text { 十ックルプレス } \\
\text { クランクプレス } \\
(400 \mathrm{t})\end{array}$ & $\begin{array}{l}\text { 冷般専用プレス } \\
(600 \mathrm{t})\end{array}$ & $\begin{array}{l}\text { プレスの多段化 } \\
\text { コールドーマ } \\
(\text { (材径 } \leqq 24 \phi)\end{array}$ & $\begin{array}{l}\text { 高速油圧プレス } \\
(2500 \mathrm{t})\end{array}$ & $\begin{array}{l}\text { トランスファ化 } \\
(800 \sim 1000 \mathrm{t})\end{array}$ & $\begin{array}{l}\text { 長ストローク化 } \\
\text { リンクプレス } \\
(\geqq 1000 \mathrm{t})\end{array}$ & $\begin{array}{l}\text { ホーマの大型化 } \\
\text { 温間ホーマ } \\
(\text { 材径 } 60 \phi)\end{array}$ \\
\hline 加工法 & 後方押出·压印 & 基本工程の組合 & 多工程の複合化 & 多方向押出し & 基本工程再検討 & 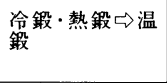 & 閉塞錘造 & $\begin{array}{l}\text { 工程·型の CAD } \\
\text { シ坔台 } \\
\text { 構築利用 }\end{array}$ \\
\hline
\end{tabular}

平成元年 8 月 9 日受付 (Received Aug. 9, 1989) (依頼解説)

* 冷間鍛造(株)取締役社長 (Cold Forming Co., Ltd., 3-186 Mihashi Omiya 330)

Key words : cold forging; warm forging ; powder forging ; work material ; tool material ; surface treatment ; forged property; forged accuracy; machinability; surface defect. 


\section{$2 \cdot 1$ 切削性の改善}

材料の被削性と塑性変形能とは互いに相反した性質 で, 鍛造品の仕上げ加工に扔いてつねにクレームの対象 となってきた。冷鍛品は焼ならし処理なしで行う仕上げ 切削が多く，表面付近は鍛造時の高温，高圧による変質 硬化層があって, 工具の損耗が激しく加工精度の維持が 困難となる. 一般に $0.5 \mathrm{~mm}$ 以上の切削代をつけること にしているが，材料の節約からできるだけ取り代を少な

\section{表 2 冷鍛用鋼材改良経過}

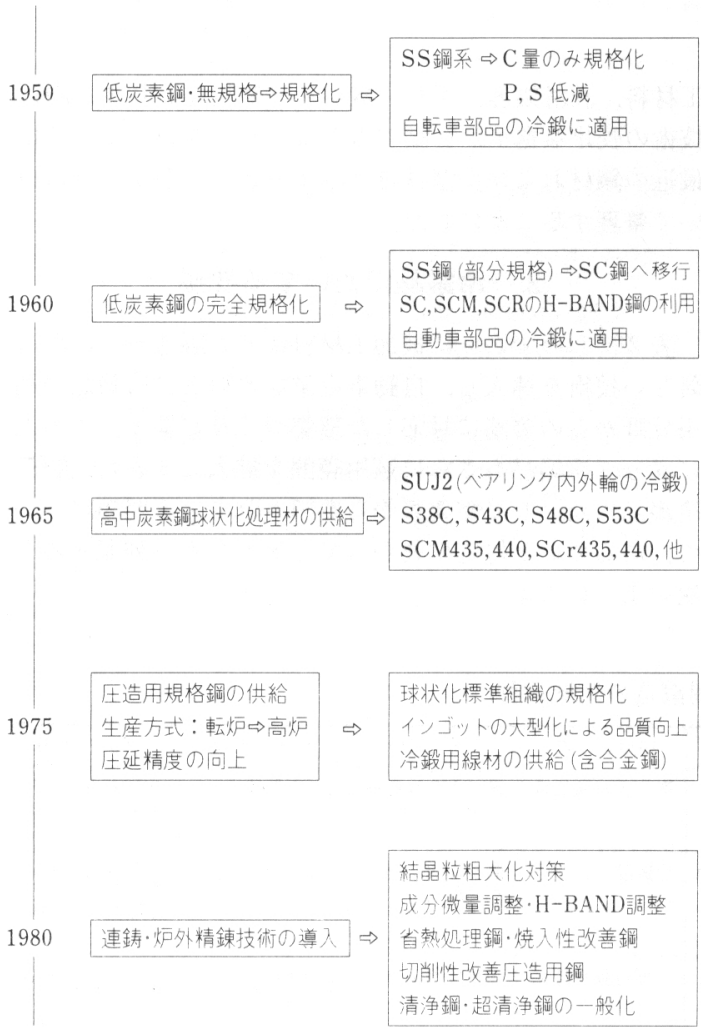

くしたい.

とくに柬切，ブローチ，タップ，ドリルなどの加工で は処理しやすい切粉形状が要望され、 NC 化が進むにつ れて材質そのものの被削性の改善が一段と問題となって きた。このようなときは，鉛快削鋼の泠鍛品が要求され るが, 写真 1 のようにファイバーフローに沿ってクラッ クが発生し, 以後の成形で大きな割れに発展する原因と なる，とくに内部割れの危険が大きいのは致命的な不安 要因である. 快削鋼で冷鍛を安全に行うためには成形限 界について詳細なデー夕の蓄積が必要であり, さらに冷 鍛性と切削性を共存する材料が研究されてきた。

鉛快削鋼については，たとえば QLTS 鋼（山陽特殊 製鋼）のように, $\mathrm{S}$ 含有量をきわめて微量に制御した 清浄鋼に, 微量の $\mathrm{Pb}$ を微細かつ均一に分散した切削性 改善圧造用鋼が開発されている ${ }^{1)}$.この材料のドリル試 験の結果と切粉形状を表 3 にしめす. 非金属介在物と切 削性改善のための添加元素の形態と分布状態の泠鍛性に およほす影響がかなり大きいとおもわれる。

\section{$2 \cdot 2$ 熱処理変形の抑制と均一化}

写真 2 のような歯形, ワンウェイクラッチの軌道面, 球面による連結部，スプラインなど，冷鍛成形した部分 を熱処理したままで使用する製品では熱処理変形による

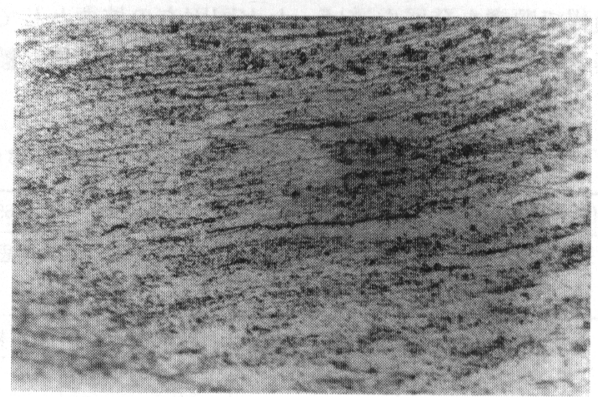

写真 1 鉛快削鋼の前方押出し軸の内部クラック $\left(\mathrm{SCM} 21 \mathrm{~L}\right.$ ，押出し比 $=4.65$ 押出し半角 $=45^{\circ}$ )

\begin{tabular}{|c|c|c|c|c|c|c|c|c|c|}
\hline \multirow{2}{*}{ 鋼 種 } & \multirow{2}{*}{$\begin{array}{l}\mathrm{S} \\
(\%)\end{array}$} & \multirow{2}{*}{$\begin{array}{l}\mathrm{Pb} \\
\%\end{array}$} & \multirow{2}{*}{$\begin{array}{l}\text { 硬さ } \\
\text { (HB) }\end{array}$} & \multirow{2}{*}{\begin{tabular}{cc} 
窎 & 孔 \\
時 & 間 \\
\multicolumn{2}{c}{ (s) }
\end{tabular}} & \multirow{2}{*}{$\begin{array}{c}\text { 工具青命 } \\
\text { V60 } \\
(\mathrm{m} / \mathrm{min})\end{array}$} & \multirow{2}{*}{ V60比 } & \multicolumn{3}{|c|}{ 切首 形 状 } \\
\hline & & & & & & & $100 \mathrm{~m} / \mathrm{min}$ & $150 \mathrm{~m} / \mathrm{min}$ & $200 \mathrm{~m} / \mathrm{min}$ \\
\hline 基本銓 & 0.013 & - & 156 & 8.48 & 65.1 & 100 & & & \\
\hline QLTS & 0.005 & 0.024 & 157 & 8.25 & 67.9 & 104 & & 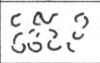 & ع ع \\
\hline $\mathrm{QL}$ & 0.018 & 0.026 & 156 & 7.70 & 69.5 & 107 & 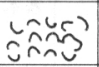 & 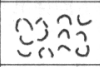 & 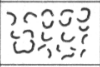 \\
\hline TL & 0.017 & 0.064 & 154 & 7.57 & 75.1 & 115 & 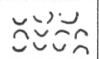 & 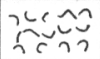 & 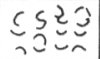 \\
\hline
\end{tabular}

杂孔時間：ドリルで $10 \mathrm{~mm}$ 穿孔するのに要した時間

工具寿命：旋盤でハイス工具寿命が 60 min になるときの切削速度

V 60 比: 基本鋼のV 60 值を 100 としたときの他の鋼種のV 60 值の比

TL : 低酸低鉛快削鋼
表 3 極低鉛快削肌焼鋼の切削試験 （山陽特殊製鋼：QL, QLTS 鋼） 
精度の低化が問題となる。たとえば歯車類のように熱処 理変形のばらつきを考虑すれば金型の摩耗代を見込めな いような厳しい公差を要求される製品がすくなくない. このような製品にたいして，熱処理変形の絶対量を小さ くするとともに材料ロッド，熱処理ロッドによるばらつ
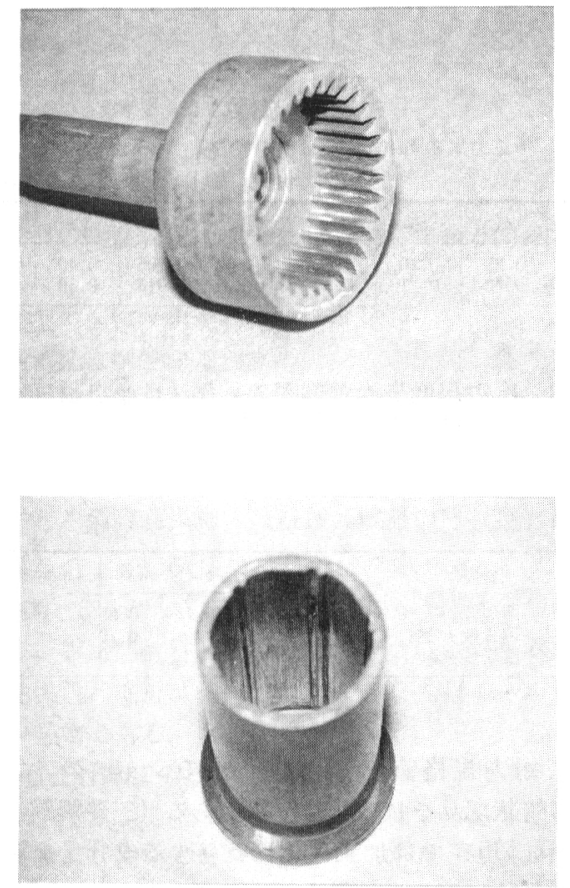

写真 2 熱処理後の冷鉔精度を要する部品
きを均一化するために, 図 1 のように焼入性能曲線の幅 を $\mathrm{HRC}< \pm 2$ に制御するような微細範囲の成分設計を 行った材料を用いて安定生産にのせることができた(三 菱製鋼 : FM 鋼シリーズ $)^{2)}$.

\section{$2 \cdot 3$ 高周波熱処理への転換}

製品の熱処理コストの低減を目的として今までの浸炭 焼入れに替えて高周波焼入れを採用するケースがしだい に多くなっている，たとえば歯車，スプライン軸はすで に部品設計の段階で合金肌焼鋼（SCM415H など）から 合金強鞁鋼（SCM435 など）に変更されている。冷鍛 加工度によっても異なるが, 原則として $\mathrm{C}>0.3 \%$ の材 料は泠鍜前に球状化焼なましが必要で, 鍛造形状が複雑 になるにしたがって均一組織でかつ球状化率 $80 \%$ 以上 の素材が要求される. 球状化焼なまし時間の短縮, ある いは通常の低温焼なまし（LA）で成形が可能な材料が 要望されている.

鉔造からの取組としては, 摩擦圧接を利用して鍛造性 のよい部分と熱処理が必要な部分にそれぞれ適当な材質 をえらんで素材段階または鍛造後に結合する方法が試み られてきた $(\text { 図 } 2)^{3)}$. しかし，接合部位の強さにたい する信頼性の評価からまだ一般的な方法として確立して いない. 一体構造のものについては写真 3 の等速ジョイ ントのハウジングにみられるように, $700^{\circ} \mathrm{C}$ 付近での温 間鍛造で粗成形を行い LA 後に加工度の小さい冷鍛で 精度の向上をはかる方法が一般化されているが, 温間域 における型材料, 潤滑処理などに問題が残っている4).

材料からの取組としては, 日産自動車などによって開 発された低炭素強䩲鋼のように, C 量の低減による LA 化, 強鞁鋼の機械的性質の保存, 高周波焼入性を保証す る成分元素 $(\mathrm{B})$ の添加の方向で開発がおこなわれ

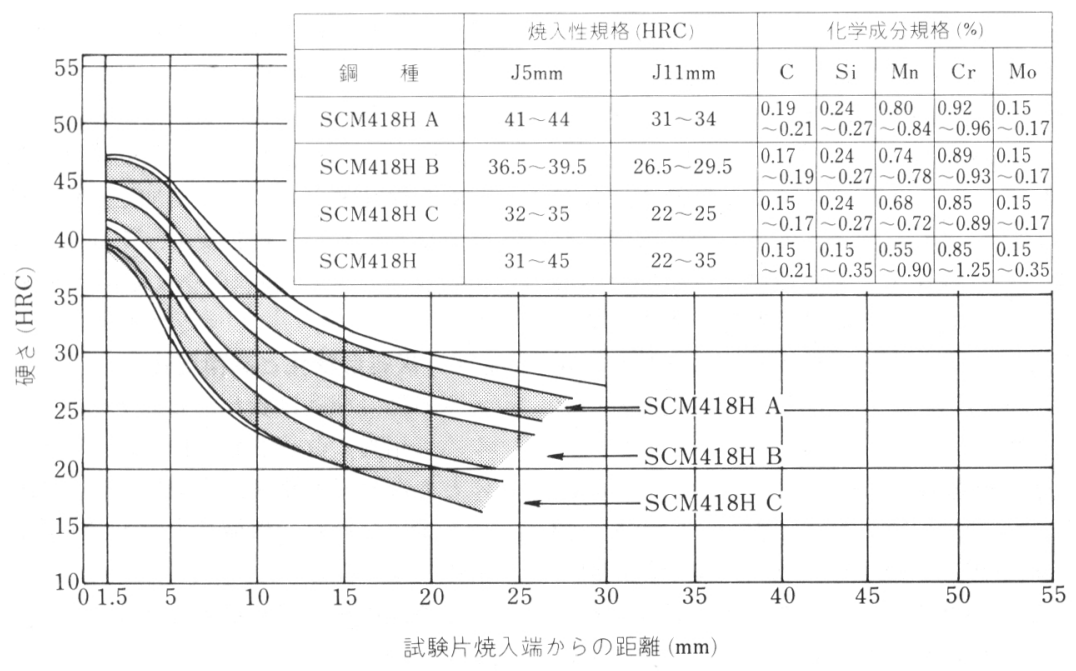

図 1 化学成分による焼入性能曲線の制御 (三菱製鋼(株)：SCM418H） 

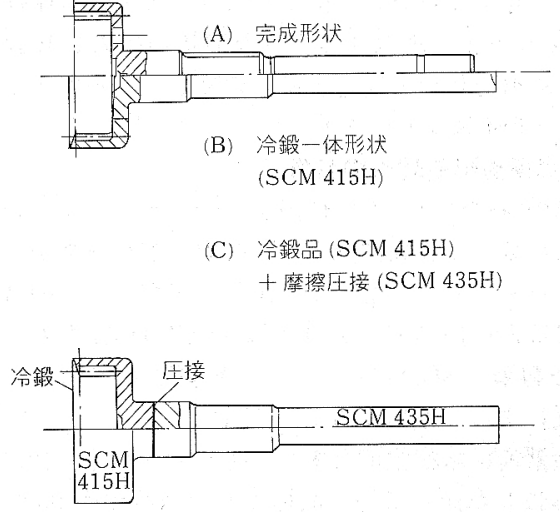

図 2 軸部品の摩擦圧接による合理化 (SCM415H-SCM435H)

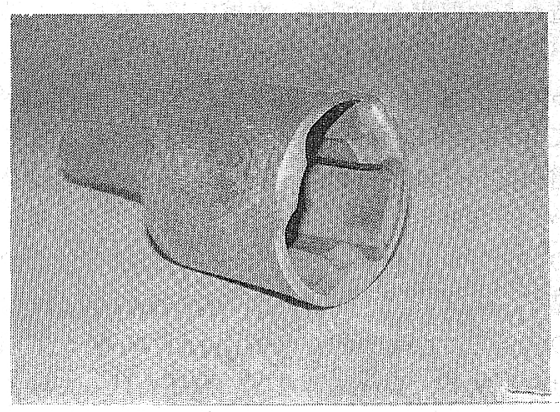

写真 3 温間鋯造-冷間サイジングによる成形

\section{た5)(図 3 ).}

表面焼入性を保証するためには般造品の表面の脱炭深 さが問題となる。鍛造品に要求される脱炭許容深さは表 $4^{6)}$ のように $0.05 \mathrm{~mm}$ とされているので, 素材段階では ごくわずかしか許されない. 現在仕様取決めのときに熱 延材で保証される全脱炭媣さは棒鋼で $0.3 \mathrm{~mm}$, 線材で $0.2 \mathrm{~mm} て ゙ ， と く に$ 熱管理を行って死延したものでも 0.15 0.2 mm といわれている. 成形による鍛造品各部 の脱炭層の厚さは素材よりも増減する。しかし冷鉔にお ける工程間の歪みとり焼なましや温鍛における加熱の影 響が付加されるので，製品の表面硬さを保証するために は冷間引抜き材やピーリング材を使用せざるを得ない現 状であるが，原価低減のためには压延材で対処したいと ころである。

\section{$2 \cdot 4$ 製品熱処理の省略}

中炭素鋼の冷鍛品の調質を省略するために，ボルト類 に適用している熱処理省略鍓を拡大利用する要望が出て いる. 以前加冷間鉎造の特長として, 加工硬化の利用 が強調されてきたが，実際の製品にたいしてはあまり応 用されていないようである。この方面では SAE1524を

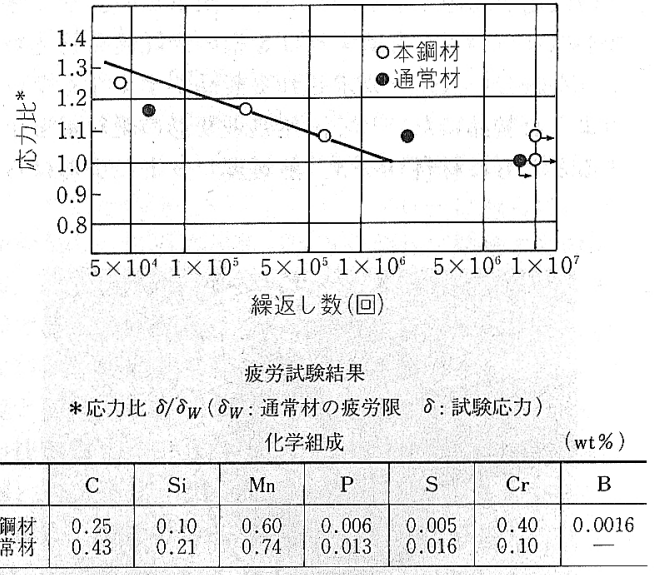

図 3 冷鉔用低炭素強鞁鋼の一例（日産自動車 $($ 株) 第二技術部による）

表 4 熱処理の種類と鉔造品の脱炭許容深さ

\begin{tabular}{|c|c|}
\hline 熱 処 理 & 許容脱炭媣さ $(\mathrm{mm})$ \\
\hline 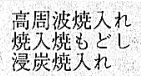 & $\begin{array}{l}0.05 \\
0.10 \\
0.30\end{array}$ \\
\hline
\end{tabular}

用いて耐力規格值で $81 \mathrm{kgf} / \mathrm{mm}^{2}$ のショックアブソー バーの管状部品を量産した実績がある（三菱製鋼宇都宮 製作所). 現在では加工硬化に寄与する成分量を調整し て使用目的に適した材料をつくることが可能なのでこの 分野の製品開発が期待される. 鍛造欠陥の発生頻度と鍛 造限界を改善し冷鍛性のよいものとするためには，現在 JIS, No. 8 以上としている結晶粒度のさらに細かい制 御が必要と考えている.これにともなう成形圧力の上昇 にたいしては型材料の耐力，鞀性の水準をさらに向上す る必要がある.

鍛造からの取組としては製品全体に均一な変形をあた える工程計画をおこなって加工硬化の部分的なばらつき を少なくすることが必要で, 中閒工程で焼なましを行わ ないコールドホーマでの鍛造にまず適用できるである j.

\section{5 複雑形状化と高精度化}

冷鍛品の精度は表 5 にしめすように初期にくらべると すでに相当に改善されている。 しかし，最近の高精度化 にともなって直角度, 平面度, 円筒度, 面粗さ, 曲がり などすべての点で機械仕上げと同程度，あるいはそれ以 上の精度が要求されている.

冷鍛品の精度に影響を与える因子は次のように要約で きる.

a)鍛造プレスの弾性変形（加圧方向の寸法精度） 
表 5 冷鍛品に要求さ机る精度水準

\begin{tabular}{|c|c|c|}
\hline 類 & 導入期 & 現 在 \\
\hline 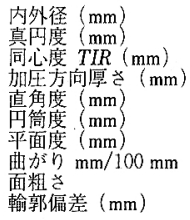 & $\begin{array}{l} \pm 0.15 \\
\leqq 0.02 \\
\leqq 0.20 \\
\pm 0.30 \\
\leqq 0.10 \\
\leqq 0.10 \\
\leqq 0.15 \\
-\end{array}$ & $\begin{array}{l} \pm 0.02 \\
\leqq 0.01 \\
\leqq 0.05 \\
\pm 0.05 \\
\leqq 0.02 \\
\leqq 0.02 \\
\leqq 0.02 \\
\leqq 0.05 \\
\leqq 4 \mu \mathrm{m} R_{\max } \\
\leqq 0.015\end{array}$ \\
\hline
\end{tabular}

注）この数值は外径 $50 \mathrm{~mm}$ の製品を対象とする 現在の数值は要求精度の上限をしめす

\section{b)金型の構造（同心度）}

c) 金型の弾性変形（加圧方向㧈よび平面方向の寸法精 度)

d)金型の製作（再製時の寸法誤差）

製品精度に影響する要素の大部分は金型の弾性変形の 絶対量, 被加工材の組織, 硬さ, 潤滑, 素材の切断重量 などによる成形荷重の変動によって支配される，金型の 弾性変形量は構成材料の縦弾性係数の值によって一義的 に決まり，現在のところ高い精度を要求される製品には 弾性係数の小さい鋼系の材料では対応できないので， $E$ $=56000 \sim 64000 \mathrm{kgf} / \mathrm{mm}^{2}$ のWC-Co 系超硬合金が用い られている. 型材料としての超硬合金にはできるだけ高 い弾性係数と抗折試験に㧍ける大きな吸収エネルギーの 共存が必要である。

\section{$2 \cdot 6$ 仕上げ加工の排除}

ニヤネットシェイプ鍛造は製品形状全体を金型によっ てすきまなく拘束する密閉鍛造化であり，投入材料の重 量に精密な均一性が要望される。この分野では冷, 温, 熱間ともに閉塞鍛造の技術がしだいに浸透してきてお り，写真 4 のような製品が実用されている4).しかし， 現在の冷間鍛造素材は大部分が棒鋼，一部板材を使用し ており，切断による重量精度の向上には素材の精度から 限界があるので完全な密閉鍛造は不可能といえる。この ため重量選別のインライン化が必要条件となっている。

図 4 のような油圧・空压を利用してプレスと型に過負 荷が起こらないような装置をもちいて密閉鉎造を㧍こな う方法が報告されている7).

材料からの対応としては，粉末材料を利用した技術が 今後の方向として模索さ机ている。

a)焼結, 熱間静水圧圧縮（HIP）した単純な形状の素 材から完全密閉で泠間鍛造をおこなう。焼結，冷鍛によ る方法でも密度の改善があるていど可能であり（真密度 比 95\% 以上)，HIPによってさらに効果が期待できる. 素材段階でのコスト比較によって今後の方向をきめるこ とになる。

b)製品に近似した形状まで焼結した予備成形品から 熱間閉塞鍛造を抢こなう。この方法は一部ではすでに㐘 車，コネクティングロッドなどの自動車部品とついて実
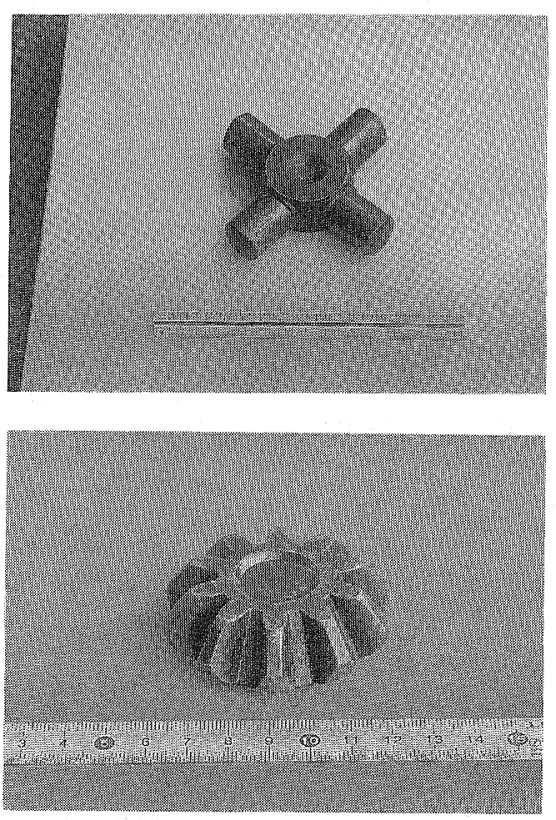

写真 4 閉塞鍛造による製品（(株)小松製作所提 供)

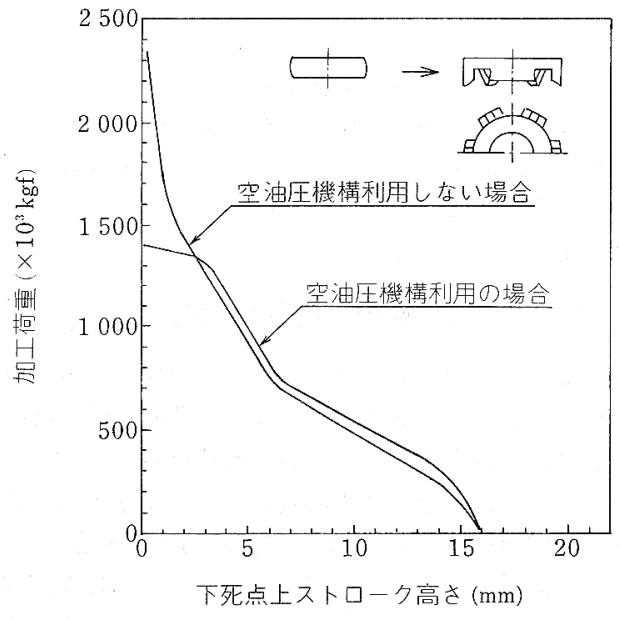

図 4 空油圧式ダイセットによる密閉鍛造の加工荷 重

用化されている。鍛造圧力，加熱温度の低下による型寿 命の向上, 表面仕上がり, 寸法精度の向上, 機械的性質 の等方性などの利点がある ${ }^{8)}$.

c)従来の焼結品の延長として焼結，HIP によって製 品をつくる，この方法では焼結体の空隙の改善が問題で あるが現在では空隙を前提として材質の高合金化によっ て要求強さを得る方向で研究が進められている. 
表 6 材料欠陥と鍛造欠陥の関係

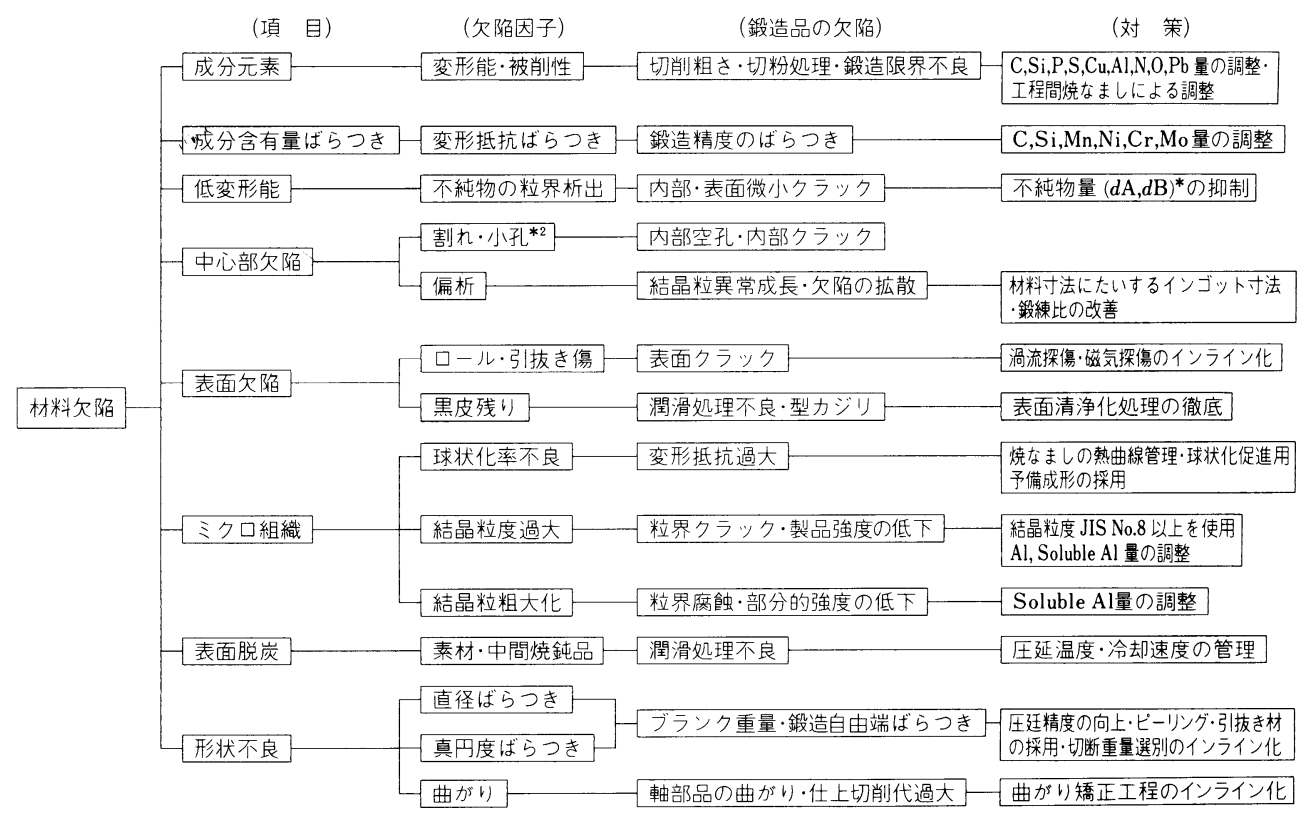

* $d \mathrm{~A}: \mathrm{A}$ 系介在物清浄度, $d \mathrm{~B}: \mathrm{B}$ 系介在物清浄度 (JIS GO555)

*2 JIS に規定する中心部のパイプ, ピット, 割れ等の欠陥は冷鍛素材に不適格として圧延段階で除外される

いずれも製品の強さを保証するために真密度のものが 要求され，コスト的には現在の鍛造品に什上げ加工を加 えた製品に匹敵することが条件となる. 粉末材料の成分 配合は自由度が高いので, 製品にたいする材料設計の面 では今までにない優位性が期待できる.

\section{3. 被加工材料の対応}

表 6 は冷鍜品の欠陷と材料欠陥との関係と対策の要点 をしめす。鍛造品にあらわれる欠陷の多くは成形時の素 材の表面および内部の応力状態と材料の特性との不一致 が原因で，製品ごとに要求品質にたいして適当な材質， 状態, 表面性状を選択することが欠陷防止の前提となる. 前述の冷鍛品にたいする要望にたいしても同様な方向で 対処すべきであろう．材料からの対応は今までの経緯か ら，おおむね次の方法でなされているようである.

\section{$3 \cdot 1$ 化学成分の用途別調整}

炉外精鍊の普及によって成分元素の含有量が微小な範 囲で調整でき，焼入性を制御した低歪み鋼など最終製品 の用途や加工方式に適した材料が供給されるようになっ た. 冷鍛業界で一時見られたような材質の低級化でコス トを下げる傾向がなくなり, 総合工程の合理化と品質の 安定のためには材料のコストを二義的に考える傾向が浸 透してきたため，多様な特定用途鋼が生産され冷鍛の品 質要求にたいして細かく対応した材料が選択できるよう
になった（表 7 ).

取鍋脱ガス法を併用して S の含有量を $0.001 \%$ 以下 に制御した清浄鋼は，冷鍛用鋼として鍛造限界の向上に よる冷鍛工程の短縮に効果がある．前述のように S の 化合物などの介在物の形態制御によって快削性を共有し た冷鍛用鋼が開発されている.

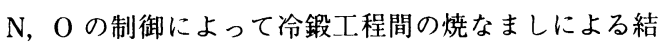
晶粗大化を抑制し，製品の機械的性質の安定をはかるこ とが可能となった. 製鋼過程に連続鋳造が導入された初 期には，低炭素鋼にたいする $\mathrm{Al}$ 添加量の変化から，焼 なましによる結晶の粗大化が顕著になった時期があった ことが報告されている.

\section{$3 \cdot 2$ 制御压延}

鋼材の圧延工程において，加熱温度，圧延温度，冷却 速度を制御する制御圧延冷却技術によって結晶組織が微 細かつ均一になり, 機械的性質を要求品質に適合させ, かつ冷鍛性を共有することが可能となった。 マイクロア ロイングによる非調質鋼 ${ }^{9)}$, 焼なまし省略鋼, 焼ならし 省略鋼がこの技術によって開発されてきた。図 $5^{10)}$ は 非調質鋼（KNCH-7）を使用した圧造ボルトの工程をし めし，他の冷鍛品についても同様な効果が期待できる. そのためには,これらの材料の冷鍛性について十分な調 査と研究が必要である.

冷鍛作業にたいして, 金型から解放したときの弾性回 
表 7 取鍋精錬鋼の特性

\begin{tabular}{|c|c|c|c|c|c|c|c|c|c|c|c|}
\hline \multirow{2}{*}{ 精 錬 方 法 } & \multicolumn{6}{|c|}{ 化学成分コントロール範囲 $(\%)$} & \multirow{2}{*}{$\begin{array}{l}\text { 焼入性 } \\
\text { (HRC) }\end{array}$} & \multirow{2}{*}{$\begin{array}{c}\text { 清浄度 } \\
\operatorname{JIS}(\%)\end{array}$} & \multicolumn{2}{|c|}{ 介 在 物 } & \multirow{2}{*}{ 用途 } \\
\hline & $\mathrm{C}$ & $\mathrm{Si}, \mathrm{Mn}, \mathrm{Cr}$ & $\mathrm{Ni}, \mathrm{Mo}$ & $\mathrm{Al}$ & 0 & $\mathrm{~S}$ & & & 形態制御 & 大きさ & \\
\hline $\begin{array}{l}\mathrm{EAF} \Leftrightarrow \mathrm{LF} \leftrightharpoons \\
\text { 鋳込み }\end{array}$ & \pm 0.01 & \pm 0.02 & \pm 0.01 & \pm 0.002 & $<25 \mathrm{ppm}$ & - & \pm 2 & $<0.08$ & $\ldots$ & - & $\begin{array}{l}\text { 焼入性制御鋼 } \\
\text { 胝焼入歪み鎆 }\end{array}$ \\
\hline $\mathrm{EAF} \Leftrightarrow \mathrm{V} \Leftrightarrow \mathrm{LF} \Leftrightarrow$ 鋳込み & \pm 0.01 & \pm 0.02 & \pm 0.01 & \pm 0.002 & $<20 \mathrm{ppm}$ & - & \pm 2 & $<0.06$ & - & - & $\begin{array}{l}\text { 脱ガス指定鋼 } \\
\text { 極清浄鋼 } \\
\text { 冷間錪造用鋼 } \\
\text { ボロン鋼 }\end{array}$ \\
\hline $\mathrm{EAF} \Leftrightarrow I J \Rightarrow L F \Leftrightarrow$ 鋳込み & \pm 0.01 & \pm 0.02 & \pm 0.01 & \pm 0.002 & $<20 \mathrm{ppm}$ & $<0.002$ & \pm 2 & $<0.02$ & 可能 & $<10 \mu \mathrm{m}$ & 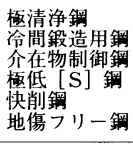 \\
\hline $\begin{array}{l}\mathrm{EAF} \Leftrightarrow \mathrm{V} \Rightarrow I J \leftrightharpoons \mathrm{IF} \leftrightharpoons \\
\text { 鋳込み }\end{array}$ & \pm 0.01 & \pm 0.02 & \pm 0.01 & \pm 0.002 & $<18$ ppm & $<0.001$ & \pm 2 & $<0.01$ & 可能 & $<10 \mu \mathrm{m}$ & $\begin{array}{l}\text { 極梅清浄鋼 } \\
\text { 極低 }[\mathrm{S}] \text { 鋼 } \\
\text { 極低 [O] 鋼 }\end{array}$ \\
\hline
\end{tabular}

$\mathrm{EAF}:$ アーク溶解 $\mathrm{LF}$ : 取鍋精錬 $\mathrm{V}$ : 取鍋脱ガス $\mathrm{IJ}:$ 粉体吹込み

(三菱製銅 (株)：FM 鋼シリーズ)

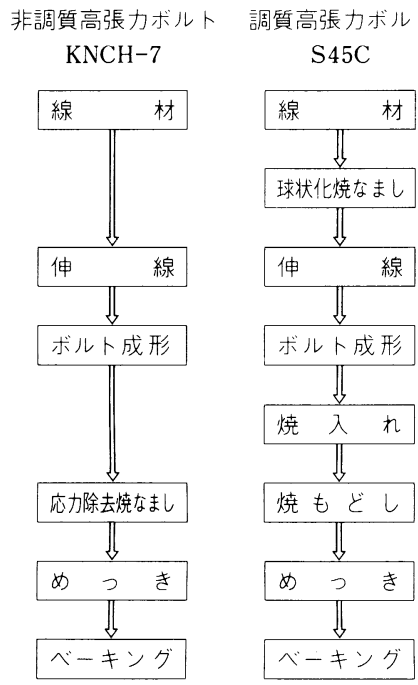

非調質ボルトの機械的性質の一例

\begin{tabular}{|c|c|c|c|c|c|c|c|}
\hline \multirow{2}{*}{ ボルト } & \multirow{2}{*}{$\begin{array}{l}\text { 応力除去 } \\
\text { 焼なま }\end{array}$} & \multirow{2}{*}{$\begin{array}{c}\text { 降伏応力 } \\
\left(\mathrm{kgf} / \mathrm{mm}^{2}\right)\end{array}$} & \multirow{2}{*}{$\begin{array}{c}\text { 引張強さ } \\
\left(\mathrm{kgf} / \mathrm{mm}^{2}\right)\end{array}$} & \multirow{2}{*}{$\begin{array}{l}\text { 伸 } \\
\mathrm{G} . \mathrm{L}=5 \mathbf{d} \\
(\%)\end{array}$} & \multirow{2}{*}{$\begin{array}{c}\langle さ ひ ゙ \\
\text { 引張強さ } \\
\alpha=10^{\circ} \\
\left(\mathrm{kgf} / \mathrm{mm}^{2}\right)\end{array}$} & \multicolumn{2}{|c|}{$\begin{array}{c}\text { 衝揧值 } \\
\left(\mathrm{kg} \cdot \mathrm{m} / \mathrm{cm}^{2}\right)\end{array}$} \\
\hline & & & & & & $25^{\circ} \mathrm{C}$ & $-50^{\circ} \mathrm{C}$ \\
\hline M10 & $200^{\circ} \mathrm{C}$ & 69 & 79 & 16 & 76 & 11 & 7 \\
\hline $\mathrm{P}=1.5$ & $\begin{array}{l}400^{\circ} \mathrm{C} \\
\times 30 \mathrm{~min}\end{array}$ & 70 & 80 & 17 & 78 & 11 & 8 \\
\hline
\end{tabular}

図 5 非調質圧造用鋼によるボルトの製造工程（神戸製鋼： $\mathrm{KNCH}-7$ )

復による製品の歪みの改善, 冷鍛品の機械的性質の安定, 鍛造前および中間工程での焼なまし（LA）の省略など に効果が期待できる.

\section{$3 \cdot 3$ 無欠陥材の供給と圧延精度の向上}

コールドホーマ製品では，冷間圧造用線材の表面欠陥 に起因するものが致命的な欠陥となる．最近，圧延工程 に扔ける表面欠陥の自動検出，自動処理が完備し，この ような事故が極めて少なくなった．圧延精度の管理技術 が改善され，1ロッドの材料については冷鍛で要求する 直径の $\pm 0.25 \%$ 以下の寸法精度のものが供給可能と なったので, 線材, 棒材とも精度改善のために引抜き工 程を経ることがしだいに減ってきた。

\section{4. 型材料の対応}

ここ 15 年にわたって, 日本塑性加工学会, 般造分科
会で冷鍛品の事例研究をおこなってきたが, 問題品とし て提起される事例はすべて金型の破損につながるもので ある.この調査研究によれば, 生産現場における型部品 の破損はおおむね図6 のような過程でおこることがわ かった.その結果として，金型材料には成形圧力に耐え る酎力と表面の微細なクラックが進展して欠損や摩耗に いたるまでの負荷の繰返し数すなわちクラックの伝播速 度との共存についてどのように配慮するかが問題として 提起され，このような特性の評価基準について論議され ている．現場における破損事例からみると，圧縮試験に おける耐力と抗折試験における吸収エネルギーによって 判断するのが実際に近い評価ができるようである.

冷鉦にたいする工具材料の取組については次のように まとめることができる.

\section{$4 \cdot 1$ 高速度鋼の多品種開発}


これまで冷鍛用金型の材料は図 7 のような圧縮耐力を 基準に選択されて扮り，SKD11 とSKH51 が基準材料 となっている. 前述の研究などで被加工材料と接触する 部分の表面の熱影響と，それによって生起されたクラッ クの伝播にたいする抵抗が寿命にたいして大きな要素と なることが明らかになったので，鞁性，耐熱性の改善の 方向に高速度鋼の高合金化が進んできた。この結果,

Mo 系高速度鋼の品種が豊富になり冷鍜作業にたいする 選択の自由度が高まり，成形圧力の限界として初期の 2 倍近くの> $400 \mathrm{kgf} / \mathrm{mm}^{2}$ まで引き上げられ, 高い局部面 压が必要な複雑な成形が可能となった。

\section{$4 \cdot 2$ 粉末高速度鋼の一般化}

溶製材料では圧延方向にたいする縱横の機械的性質の 差が金型の破損に影響するので，アイソトロピー材（日 立金属）のような等方質を目指した工具材料が開発され た。現場の経験から縞状偏析が粗く明暌な材料は金型の

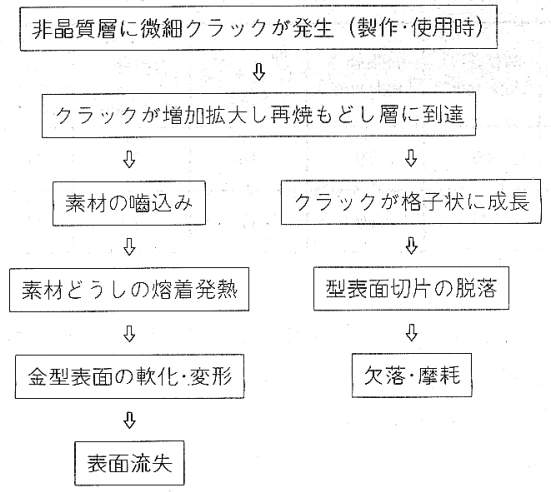

図 6 金型表面の破損過程の考察
使用初期に破損が頻発する䝨向が大きい（写真 5 ）。こ の現象は大径溶製素材から削り出した金型に顕著にあら われ，粉末高速度鋼を使用して寿命のばらつきを均一に することができた。

粉末高速度鋼は写真 6 のように, 表面の摩耗状況が溶 製材とことなり構成粉粒の脱落によるため，成形された 製品の表面は材料の流動による筋傷がすくなく，仕上が りが極めて良好である。また粉末の配合によって溶製材 では不可能な高合金の材料をつくることができるので， たとえば HAP シリーズ（日立金属）のように溶製高速 度鋼と超硬合金との中間の特性の材料を得る可能性があ る. しかし鍛造精度に影響する弾性係数の向上の面では 期待できない.

\section{$4 \cdot 3$ 超硬合金の HIP 処理}

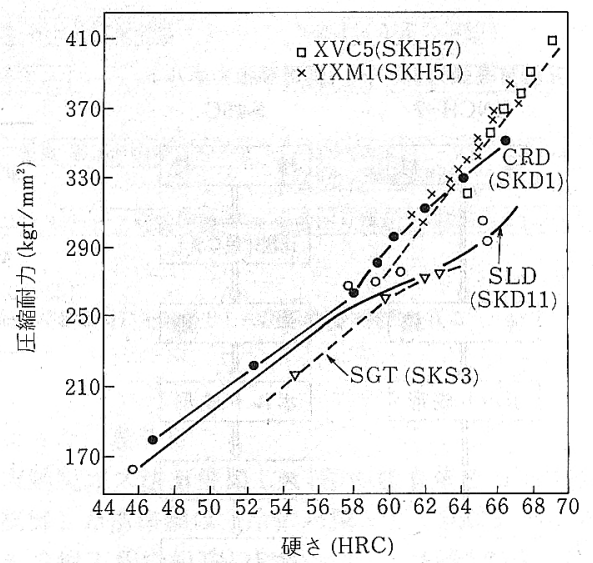

図 7 工具材料の圧縮耐力（日立金属: 技術資料 No. 288)

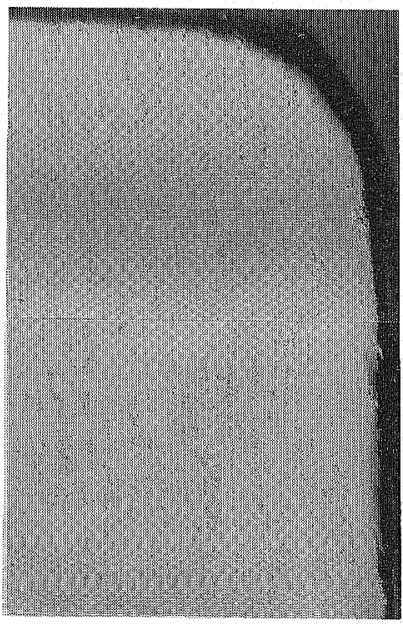

(A) 素材径 $\phi 60$

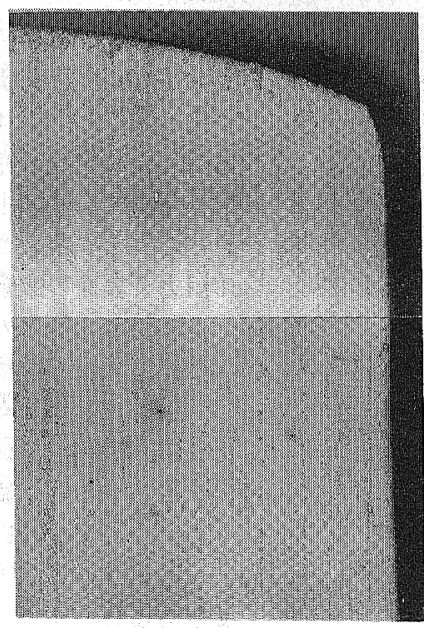

(B)素材径 $\phi 110$
写真 5 工具材料の直径寸法による縞 状偏析の差異 (歯車押出しパンチ歯形 部) SKH 51, HRC $62(\times 45)$ 
成形部外観
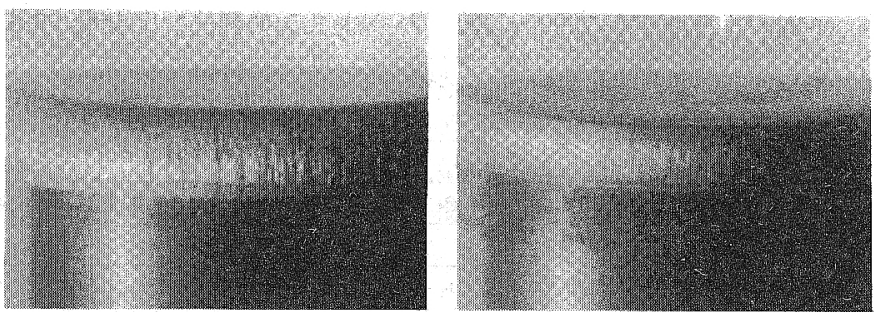

$\mathrm{R}$ 部断面
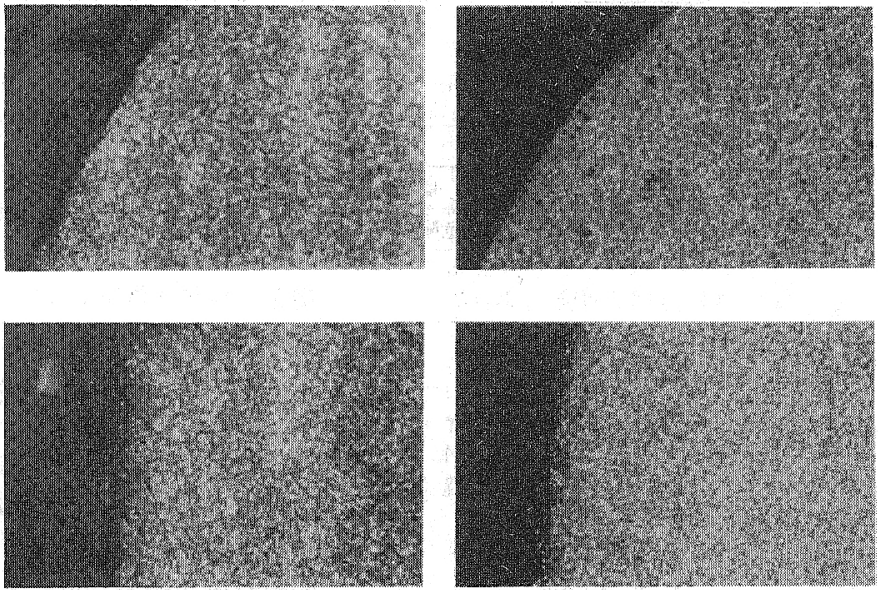

(A)SKH 51, HRC64 加工数: 50000

(B) ASP 23, HRC63.8

加工数 : 80000

写真 6 後方押出しパンチの先端摩耗比較

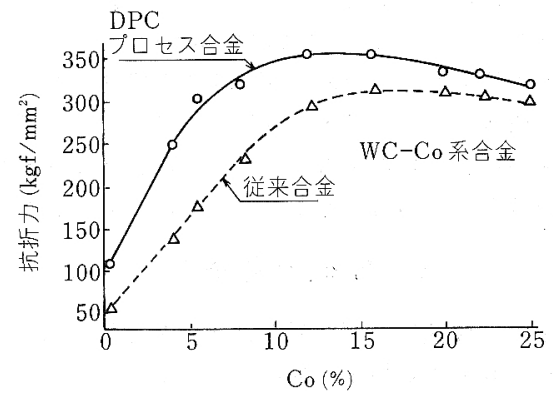

DPCプロセスと従来法の焼結条件

\begin{tabular}{|c|c|c|}
\hline 合金製造法 & 焼 結温 度 & HIP 温度 \\
\hline $\mathrm{DPC}$ プロセス & $1360^{\circ} \mathrm{C}$ & $1330^{\circ} \mathrm{C}$ \\
\hline 従 来法 & $1450^{\circ} \mathrm{C}$ & \\
\hline
\end{tabular}

図 8 HIP 処理によるWC-Co 合金の改善（ダイ ジェット工業 : DPC プロセス)

冷間鈮造の初期では金型の靱性を重視して Co>25\% の超硬合金（G6－8）が用いられていた，粉末焼結後， 熱間静水圧圧縮を行う HIP 処理が応用されて，図 80
ようにC 0 含有量を少なくしても抗折強さの高いものが 得られ，従来の合金では抗折力が急激に低下する Co $15 \%$ のものまで使用できるようになった ${ }^{11)}$. Co 含有量が少ないほど弾性係数が高く製品精度の管理が容 易になるので，超硬合金は耐摩耗性よりも高精度品に用 いる傾向が一般的となって扔り，これはHIP 処理の大 きな効果といえる.

パンチ材などにたいしてWCの粒度をく2um に微細 化すると引張強さのばらつきが少なくなるといわれてい 万(図 9 ).

超硬合金の摩耗状況の調査によって，Co が被加工物 の表面とともに流動してWC 粒が一緒に脱落すること がわかった。したがって，超硬金型にもCVD 処理を施 し表面に TiN 皮膜を生成してよい結果が得られている.

\section{4 表面処理の一般化}

1971 年から TD 処理が塞用化された。この方法は熱 拡散処理 ${ }^{12)}$ (化学的蒸着法 (CVD) および熱反応析出 • 拡散法（TRD））によって金型表面に $\mathrm{V}, \mathrm{Nb}, \mathrm{Cr}, \mathrm{Ti}$ などの炭化物を形成し，耐摩耗性，耐焼付性を改善する もので，打抜き金型などに応用して大幅な寿命の延長が 確認された. 表 8 はこの種の皮膜処理法の比較をしめ 
表 8 工具表面の耐摩耗皮膜処理法の比較 ${ }^{12)}$

\begin{tabular}{|c|c|c|c|c|c|c|c|}
\hline & & \multicolumn{3}{|c|}{ TRD（各種炭化物） } & \multicolumn{2}{|c|}{ CVD } & PVD $(\mathrm{TiN})$ \\
\hline & & 溶融塩 & \multicolumn{2}{|c|}{ 粉 末 法 } & \multirow{2}{*}{$\begin{array}{c}\text { 中·高温 } \\
(\mathrm{TiC}, \mathrm{TiCN})\end{array}$} & \multirow{2}{*}{$\stackrel{\text { 低 温 }}{\left(\mathrm{W}_{2} \mathrm{C}\right)}$} & \multirow{2}{*}{ イオンプレーティング } \\
\hline & & 浸 漬 & 流動層 & パック & & & \\
\hline \multirow{6}{*}{$\begin{array}{l}\text { 方 } \\
\text { 法 }\end{array}$} & 方法 & 塩浴中に浸漬 & 粉末層中に浸漬 & 容器ごと炉中加熱 & \multicolumn{2}{|c|}{ ハロゲンガス中で加熱 } & イオンの蒸着 \\
\hline & 雲囲気 & 大気 & Ar & 大気 & \multicolumn{2}{|c|}{$\mathrm{H}_{2}$} & 減圧 $\mathrm{N}_{2}$ \\
\hline & 処理剂 & $\begin{array}{c}\text { 〈ほう砂〉 } \\
\text { 金属粉 }\end{array}$ & \multicolumn{2}{|l|}{$\begin{array}{c}\text { 〈金属粉〉 } \mathrm{Al}_{2} \mathrm{O}_{3} \\
\text { ハロ゙化物 }\end{array}$} & \multicolumn{2}{|l|}{$\begin{array}{l}\left\langle\mathrm{H}_{2}\right\rangle \mathrm{C}_{m} \mathrm{H}_{n} \\
\text { ハロデン化物 }\end{array}$} & $\begin{array}{l}\text { 〈金属〉 } \\
\mathrm{N}_{2}\end{array}$ \\
\hline & 使用可母材 $\quad \mathrm{C}$ を含 & \multicolumn{3}{|c|}{ Cを含む金属, サーメット, 超硬合金, 七ラミックス } & \multicolumn{3}{|c|}{ 金属, サーメット, 超硬合金, セラミックス } \\
\hline & 品物温度 $\left({ }^{\circ} \mathrm{C}\right)$ & $800 \sim 1200$ & $800 \sim 1100$ & $800 \sim 1200$ & $900 \sim 1050$ & $500 \sim 600$ & $200 \sim 600$ \\
\hline & 層成長速度 $(\mu \mathrm{m} / \mathrm{h})$ & \multicolumn{3}{|c|}{$2 \sim 10$} & \multicolumn{2}{|c|}{$2 \sim 10$} & $30-40$ \\
\hline \multirow[b]{2}{*}{ 品 } & 実用上限厚さ（ $\mu \mathrm{m} ）$ & \multicolumn{3}{|c|}{$\sim 20$} & \multicolumn{2}{|c|}{-10} & $\sim 5$ \\
\hline & 層厚さ均一性 & \multicolumn{3}{|c|}{ 大 } & \multicolumn{2}{|c|}{ 中 } & 小 \\
\hline \multirow{2}{*}{ 質 } & 層の密着性 & \multicolumn{3}{|c|}{ 大, ばらつき小 } & & 中 & 小, ばらつき大 \\
\hline & ひずみ発生 & \multicolumn{3}{|c|}{ 危険性あり } & & \multicolumn{2}{|c|}{ ほとんとなし } \\
\hline
\end{tabular}

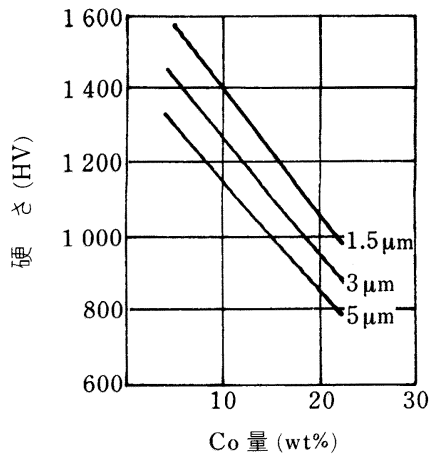

図 9 WC-Co 合金に扔けるWC 粒度と硬さの関 係 (ダイジェット工業 : 微粒合金)

$す^{12)}$.

冷鍛金型には $\mathrm{VC}, \mathrm{TiC}, \mathrm{TiN}$ の単一皮膜, $\mathrm{TiC}+$ $\mathrm{TiN}$ の複合あるいは積層皮膜が用いられている。最近 では酎摩耗, 酎焼付性は型材の要求特性から除外し, 皮 膜処理によってカバーする考えに変わってきた．

冷鍛のように作業面圧が高いときには，金型母材に塑 性変形が起これば皮膜にクラックを生じ剝離することに なる。 また炭化物皮膜は母材の C の一部を吸収して形 成されるので皮膜の下部に $\mathrm{C}$ 濃度の低い層ができて塑 性流動が促進される. したがって，今のところ対象とな る金型によって効果に著しく差異があるといわれてい る. 最近，処理に必要な $\mathrm{C}$ を外部から供給する方法が 検討されているようである. 皮膜の密着度は処理前の表 面粗さ, 表面の清浄度に敏感で, 前処理が適当でないと 剝離しやすい.

皮膜の形成は金型材料の熱処理温度に近い高温 $(800$ 〜 $1200^{\circ} \mathrm{C}$ ) で行われるので, 所定の熱処理をした部品
を処理後に再度熱処理する必要があり，母材に結晶粒粗 大化の危険があり，皮膜処理および熱処理変形によって 金型の精密な寸法管理が困難である. 型製作からみて処 理温度は型材の焼もどし温度より低くして熱処理による 影響をなくすることが望ましい.この点でイオンプレー ティングのような処理温度の低い $\left(200 \sim 600^{\circ} \mathrm{C}\right)$ 物理 的蒸着法 (PVD) が有利であるが, TiN 皮膜の厚さと 密着度が高温処理より劣る，皮膜厚さと剥離寿命の関係 は数量的にまとめられていないが，他の表面硬化処理と 同様に厚さについて有効な限界があるように思われる. 最近処理エネルギーをあげて皮膜厚さを改善して相当の 効果が得られているので, 今後の動向が注目されている.

従来から使用されている夕フトライド処理, おもに熱 鍛型に利用されているイオン窒化など金型の表面処理技 術は多種多様のものがある．それぞれに正当な評価を与 えて利用分野をきめることが当面の課題といえよう.

\section{5. 今後の見通し}

これまで冷間鍛造は型材料の種類の多様化と品質の改 良に支えられて成形技術を発展させ, 品質が安定した複 雑な形状の製品をつくってきた．とくに超硬合金に対す る評価の転換, 粉末高速度鋼の一般化はこの傾向を加速 させている. 加工用材料は製品の品質にたいする要求が 成形技術上の要求品質に合致する方向に改良されてき た.この傾向は今後も継続することが十分予想できる.

冷鍛品の競合相手はロストワックス鋳造によって代表 される精密鋳造品と考えられていたが, 最近の動向から は粉末焼結品が本命とされている. 焼結の弱点といわれ ている強さとコストについては早晚解決する見通しが得 られており, 溶製材の鍛造品で得られない利点があるこ とも確かである. 熱間鍛造と冷間鍛造が温間鍛造として 加工温度の面で融合したように, 冷間鍛造と粉末焼結が 
材料面で融合する可能性が予想できる.

それぞれの製品にたいするもっとも合理化された生産 工程のなかで, 冷鍛品はますます高精度となり, 後加工 の徹底した省略と形状の複雑化が進み, 機能的な面だけ でなく外観的な面も強調されてくる．したがって，いま まで比較的強かった型材料とのかかわりがしだいに加工 材料に移っていくように思われる. 高 $\mathrm{Ni}$ 磁性材, 耐熱 鋼, 加工硬化性の強いステンレス鋼など冷鍛から敬遠さ れていた難成形材についても, 最近ようやく冷温鍛化が 研究され，あるていど量産見通しが得られている.

潤滑処理にたいする加工材質の影響はこれまであまり 問題にされていなかった，たとえば，低炭素 $\mathrm{Al}$ キルド 鋼は潤滑用のりん酸要鉛皮膜が形成されにくいなどの指 摘については，まだ明瞭な見解と対策が得られていない. 温間鍛造の閏滑方式についても模索状態から脱却してい ない.このような冷温間鍛造と他の技術との接点にある 問題について更に範囲を広げて詳しく追求していく必要 を痛感する。

\section{6.む す び}

冷間鉭造に従事する立場から，材料に関するいろいろ な問題について現状を正確に把握することが今後部品工 業が発展する方向を判断する前提になると思われるので
手元の資料を整理してみた。成形技術そのものについて も, 冷, 温, 熱間鍛造とも未解決のまま残されているこ とが非常に多く, 今後各方面の協力を得て解決したいき たいと念願している。この稿で参照させていただいた資 料を提供された各位をはじめ，日ごろいろいろとご意見 とご指導を賜っている諸氏に深く謝意を表するしだいで ある。

\section{文献}

1 ）山陽特殊製鋼: 特殊鋼, 36 (1987) 3, p. 20

2 ）三菱製鋼(株)技術資料

3 ）澤辺 弘: 日本塑性加工学会, 鈠造分科会, 第 18 回冷温 間実務講座前刷 (1988), p. 32

4 ) 日本塑性加工学会鍛造分科会温熱間鍛造研究班: 温間鍛造 事例デー夕集 (1989)

5 ) 白産自動車第二技術部: 素形材, 30 (1989) 1, p. 30

6 ）高橋昭夫, 澤辺 弘: 塑性と加工, 17 (1976), p. 644

7 ) 村松 勁, 森田一宏, 今井敏博: 塑性と加工, 28 (1987), p. 999

8 ) 黒石農士: 塑性と加工, 27 (1986), p. 1117

9 ）礒川憲二, 田中良治: 日本金属学会会報, 22 (1983), p. 437

10）山田凱朗: 笰造技報 (1983) 15, p. 22

11）青山 進: ダイジェット工業(株)Technical Report, No. 103 (1979)

12）新井 透: 金属, 59 (1989) 7, p. 66 